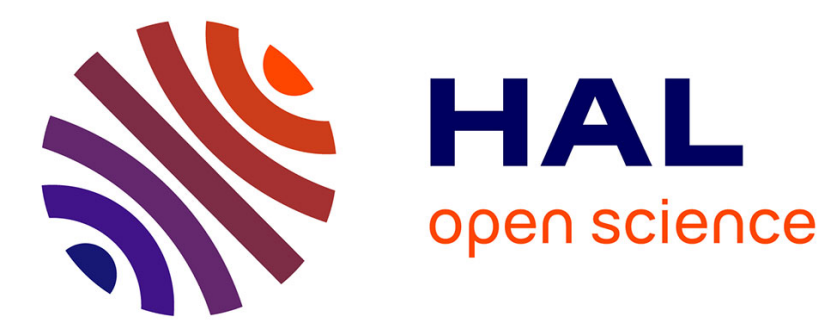

\title{
Sn02 Aerogels: Towards Performant and Stable PEFC Catalyst Supports
}

Guillaume Ozouf, Gwenn Cognard, Frédéric Maillard, Laure Guetaz, Marie Heitzmann, Christian Beauger

\section{- To cite this version:}

Guillaume Ozouf, Gwenn Cognard, Frédéric Maillard, Laure Guetaz, Marie Heitzmann, et al.. Sn02 Aerogels: Towards Performant and Stable PEFC Catalyst Supports. 228th ECS Meeting - Polymer Electrolyte Fuel Cells 15 (PEFC 15) , Oct 2015, Phoenix, AZ United States. pp.1207-1220, 10.1149/06917.1207ecst . hal-01253618

\section{HAL Id: hal-01253618}

https://hal-mines-paristech.archives-ouvertes.fr/hal-01253618

Submitted on 11 Jan 2016

HAL is a multi-disciplinary open access archive for the deposit and dissemination of scientific research documents, whether they are published or not. The documents may come from teaching and research institutions in France or abroad, or from public or private research centers.
L'archive ouverte pluridisciplinaire HAL, est destinée au dépôt et à la diffusion de documents scientifiques de niveau recherche, publiés ou non, émanant des établissements d'enseignement et de recherche français ou étrangers, des laboratoires publics ou privés. 


\title{
$\mathrm{Sn0}_{2}$ Aerogels: Towards Performant And Stable PEMFC Catalyst Supports
}

\author{
Guillaume Ozouf ${ }^{\mathrm{a}}$, Gwenn Cognard ${ }^{\mathrm{b}}$, Frédéric Maillard ${ }^{\mathrm{b}}$, Laure Guétaz ${ }^{\mathrm{c}}$, Marie \\ Heitzmann $^{\mathrm{c}}$, and Christian Beauger ${ }^{\mathrm{a} *}$
}

\author{
a MINES ParisTech, PSL Research University PERSEE - Centre procédés, énergies \\ renouvelables et systèmes énergétiques, CS 10207 rue Claude Daunesse 06904 Sophia Antipolis \\ Cedex, France \\ ${ }^{\mathrm{b}}$ Univ Grenoble Alpes, UMR CNRS 5279, LEPMI, F-38402 St Martin d'Hères, France \\ ${ }^{c}$ CEA Grenoble, LITEN, DEHT, F-38054 Grenoble, France \\ *corresponding author
}

Carbon free catalyst support were synthetized from tin dioxide aerogels obtained after supercritical $\mathrm{CO}_{2}$ drying of gels synthetized following an acid catalyzed sol-gel route, starting from metal alkoxides precursors. Sb doping at 10 at\% was realized adding antimony alkoxide to the sol. The nanoscale morphology can be controlled during the sol-gel synthesis route and is retained after drying. The effect of doping with $\mathrm{Sb}(\mathrm{V})$ on the structure and the morphology of the material was investigated by XRD, SEM and nitrogen sorption. Our materials showed reasonable specific surface areas $\left(85 \mathrm{~m}^{2} / \mathrm{g}\right)$. The bimodal narrow pore size distribution, centered on around 25 and $45 \mathrm{~nm}$ after calcination at $600{ }^{\circ} \mathrm{C}$, is particularly well adapted to the foreseen application. Sb doped aerogel exhibited an impressive improvement of electronic conductivity, reaching $0.13 \mathrm{~S} / \mathrm{cm}$. This is representing a 4 orders of magnitude increase compared to pure $\mathrm{SnO}_{2}$. This level of conductivity is almost equivalent to that of carbon Vulcan XC-72R measured in the same conditions $(4 \mathrm{~S} / \mathrm{cm})$. These properties make $\mathrm{SnO}_{2}$ : $\mathrm{Sb}$ a very promising material as catalyst support for PEFC cathode. Three different methods of platinum deposition on $\mathrm{SnO}_{2}$ : $\mathrm{Sb}$ surface were studied. TEM and analysis was used to visualized $\mathrm{Pt}$ nanoparticles dispersion and sizes. Electrochemical features, like ECSA and ORR catalytic activities, of the best electrocalalysts in term of dispersion were investigated by the mean of RDE. Reduction by ethylene glycol method show higher mass catalytic activity than reference carbon-based electrocatlyst.

\section{Introduction}

Polymer electrolyte fuel cells (PEFC) are promising power sources candidate for transportation, stationary and portable applications. The oxidation of hydrogen and the reduction oxygen need to be catalyzed. To limit platinum quantities, electrocatalysts are composed of platinum nanoparticles dispersed on a support. Nanoparticles allow to optimize the surface/volume ratio of catalyst particles while high surface area support are beneficial to the catalyst particles dispersion. 
Concerning the nanoparticles' size, Mukerjee et al. have demonstrated an optimum between 3 and $4 \mathrm{~nm}$ for Pt deposited on carbon (1). Bigger particles lead to less fraction of Pt atom which will participate to surface reactions. Smaller particles will increase the number of surface metal at low coordination number, with the consequence of increasing adsorption heat of the oxygen intermediate.

Commercial electrocatalyst are based on carbon blacks (CB) as supports since they show a high electronic conductivity and a high specific surface area. Highly homogenous dispersions are now achieved and depositions of Pt nanoparticles on carbon black surface are now well controlled.

However carbon blacks are thermodynamically unstable in fuel cells operating conditions (high relative humidity and low $\mathrm{pH}$ ). They tend to corrode to carbon dioxide $(2,3)$. This corrosion causes a contact loss between the conductive carbon support and the catalyst. Losses of performance are also explained by mechanisms of dissolution and coalescence of platinum particles (4).

As an alternative corrosion resistant catalyst support, tin dioxide has shown interesting properties. This oxide is thermodynamicaly stable in PEMFC operating condition (5).

Even if undoped $(6,7)$ or doped $(8-10) \mathrm{SnO}_{2}$ based electrocatalysts reported in the literature have good resistance to aging tests, most of them show weaker initial performance than $\mathrm{Pt} / \mathrm{CB}$. Metal oxide materials used in these studies do not have at the same time high enough electronic conductivity and adapted morphology to allow good platinum nanoparticles deposition.

Platinum nanoparticle dispersion is of major importance to get viable electrocatalyst. Kakinuma et al. and Senoo et al. have successfully prepared electrocatalysts showing high performance. For Kakinuma electrocatalysts, Pt nanoparticles were homogenously dispersed on $\mathrm{SnO}_{2}$ : $\mathrm{Sb}$ (Pt loading, $12.3 \mathrm{wt} \%$ ) and $\mathrm{SnO}_{2}: \mathrm{Nb}$ (Pt loading, $10 \mathrm{wt} \%$ ) with $\mathrm{Pt}$ particles size of $3 \mathrm{~nm}(11,12)$. They obtained similar an ORR mass activity than for $\mathrm{Pt} / \mathrm{CB}$ with a higher durability. Senoos' electrocatalysts are constituted of $3.1 \mathrm{~nm} \mathrm{Pt}$ nanoparticles dispersed on $\mathrm{SnO}_{2}$ : Ta (Pt loading, $15.8 \mathrm{wt} \%$ ). ORR mass activity and durability was also higher than that of Pt/CB (13). Several studies report that $\mathrm{SnO}_{2}$ based electrocatalysts have a higher specific activity than carbon blacks based ones $(10,11)$. This phenomenon is ascribed to the supposed strong interaction between platinum and the support (SMSI) $(14,15)$. These interactions can modified Pt electronic structure (16).

$\mathrm{SnO}_{2}$-based electrocatalysts also show better tolerance to carbon monoxide (17-19). This could be explained by the $\mathrm{CO}$ oxidation by hydroxyl group in the $\mathrm{SnO}_{2}$ surface (20). Compared to carbon as support, they have a higher tendency to induce a four electrons process for the oxygen reduction reaction (ORR). $\mathrm{H}_{2} \mathrm{O}_{2}$ is thus produced in lower quantity what is beneficial to avoid membrane degradation (21).

In this study, Pt nanoparticles were dispersed on a $\mathrm{SnO}_{2}: \mathrm{Sb}$ (10 at\%) aerogel synthetized in our laboratory. This material has been selected for its adapted physicochemical properties in terms of electronic conductivity and morphology. Different $\mathrm{Pt}$ deposition methods were tested and compared. Samples showing the best Pt nanoparticles 
dispersion were electrochemically characterized through the calculation of their electrochemical surface area (ECSA) and the evaluation of their catalytic activity toward oxygen reduction reaction (ORR).

\section{Experimental}

\section{Catalyst Support Synthesis Route}

$\mathrm{SnO}_{2}$ : $\mathrm{Sb}(10$ at\%) aerogel was synthesized by sol-gel route, using metal alkoxide precursors: $\mathrm{Sn}(\mathrm{OiPr})_{4}$ (Alfa Aesar, $10 \% \mathrm{wt} / \mathrm{vol}$ in $\left.\mathrm{iPrOH}\right)$ and $\mathrm{Sb}(\mathrm{OiPr})_{3}$ (Alfa Aesar). Two solutions (A \& B) were prepared. A solution A containing $5.75 \mathrm{~mL}$ of tin isopropoxide and $0.041 \mathrm{~mL}$ of antimony isopropoxide in $4.5 \mathrm{~mL}$ of isopropanol (Acros Organics, 99.5\%) was placed under magnetic stirring. A solution $\mathrm{B}$ of $0.058 \mathrm{~mL}$ of nitric acid (Alfa Aesar, $2 \mathrm{~N})\left(\mathrm{HNO}_{3} / \mathrm{Sn}=0.072\right)$ in $0.035 \mathrm{~mL}$ of water $\left(\mathrm{H}_{2} \mathrm{O} / \mathrm{Sn}=3.06\right)$ and 4.5 $\mathrm{mL}$ of isopropanol $(\mathrm{iPrOH} / \mathrm{Sn}=119)$ was also mixed under magnetic stirring. The solution B was then slowly dripped into the solution A and a gel formed after few minutes. The gel was then covered with isopropanol to prevent any drying. It was left as is for 48 hours (aging) and then washed with isopropanol three times a day for two days. After washing, resulting gel was dried under $\mathrm{CO}_{2}$ in supercritical conditions $(80 \mathrm{bar}$, $40{ }^{\circ} \mathrm{C}$ ) to get the aerogel. The obtained solid was heat treated under air at $600^{\circ} \mathrm{C}$ during $5 \mathrm{~h}$. After calcination, the sample color turned blue.

\section{Platinum Deposition Protocols}

Pt nanoparticles were deposited on the surface of the selected catalyst support according to three main methods, labelled A, B and C. Quantities were adjusted to get Pt loadings between 20 and $30 \mathrm{wt} \%$.

The method A is based on support impregnation with a platinum salt: $\mathrm{H}_{2} \mathrm{PtCl}_{6}, 6 \mathrm{H}_{2} 0$. $\mathrm{SnO}_{2}$ : Sb was first dispersed in $4 \mathrm{~mL}$ of water by mean of sonication. $\mathrm{H}_{2} \mathrm{PtCl}_{6}, 6 \mathrm{H}_{2} \mathrm{O}$ dissolved in $10 \mathrm{~mL}$ of water was then added to the dispersion of $\mathrm{SnO}_{2}: \mathrm{Sb}$. The dispersion was heated at $60{ }^{\circ} \mathrm{C}$ under magnetic stirring until total solvent evaporation. The resulting powder was calcined at $350{ }^{\circ} \mathrm{C}$ under air during $1 \mathrm{~h}$ to form $\mathrm{PtO}$ and removed organic components. The powder was then washed with water until elimination of $\mathrm{Cl}^{-}$from the filtrate $\left(\mathrm{Cl}^{-}\right.$ions were detected from $\mathrm{AgCl}$ precipitation with $\mathrm{AgNO}_{3}$ solution). Reduction of platinum was performed either by calcination at $200{ }^{\circ} \mathrm{C}$ under $\mathrm{H}_{2}$ during $3 \mathrm{~h}$ or under UV irradiation (300 W Hg lamp, during 1, 3 or $5 \mathrm{~h}$ ). With this last method, Yang et al. show that platinum was reduced due to the photo-generated electron-hole pairs on the oxide sites (22).

The method $\mathrm{B}$ is also based on support impregnation with $\mathrm{H}_{2} \mathrm{PtCl}_{6}, 6 \mathrm{H}_{2} \mathrm{O}$, but the $\mathrm{pH}$ was adjusted during impregnation. $\mathrm{SnO}_{2}: \mathrm{Sb}$ was dispersed in $4 \mathrm{~mL}$ of water by the mean of sonication. $\mathrm{H}_{2} \mathrm{PtCl}_{6}, 6 \mathrm{H}_{2} \mathrm{O}$ dissolved in a mixture of $160 \mathrm{~mL}$ of $\mathrm{H}_{2} \mathrm{O}$ and $40 \mathrm{~mL}$ of EtOH was added to the dispersion of $\mathrm{SnO}_{2}$ : Sb. pH was adjusted to 2.8, 3.8 and 4.8 by adding corresponding amount of $\mathrm{NaOH}$ or $\mathrm{HCl}$. The dispersion was left under magnetic stirring during $24 \mathrm{~h}$ at room temperature before filtration and washing with water. The resulting powder was calcined at $350{ }^{\circ} \mathrm{C}$ under air during $1 \mathrm{~h}$. Pt reduction was performed in the same condition than for method A. 
In the method $\mathrm{C}, \mathrm{Pt}$ nanoparticles were first formed by dissolving $140 \mathrm{mg}$ of $\mathrm{H}_{2} \mathrm{PtCl}_{6}$, $6 \mathrm{H}_{2} \mathrm{O}$ in $100 \mathrm{~mL}$ of ethylene glycol (EG). EG will act both as a stabilizer and a reducing agent of $\mathrm{Pt}$ nanoparticles. The $\mathrm{pH}$ was adjusted to 10 by adding corresponding amount of $\mathrm{NaOH}$. The solution was refluxed at $160{ }^{\circ} \mathrm{C}$ during $30 \mathrm{~min}$ under argon. $\mathrm{SnO}_{2}: \mathrm{Sb}$ dispersed in $4 \mathrm{~mL}$ of water was then adding and the $\mathrm{pH}$ was reduced to 2 by addition of $\mathrm{H}_{2} \mathrm{SO}_{4}$. The dispersion was left under magnetic stirring during $24 \mathrm{~h}$ at room temperature before filtration and washing with water.

\section{Characterization}

XRD measurements were performed using an X'Pert pro, Philips diffractometer $(\mathrm{Cu}$ $\mathrm{K} \alpha$ of $\lambda=1.5405 \AA$ ). The diffractometer was operated at $45 \mathrm{kV}$ and $30 \mathrm{~mA}$. Data were collected in steps of $0.05^{\circ}$ from $20^{\circ}$ to $90^{\circ}$ in $2-\theta$ mode with Pixcel counter.

Morphologies were analyzed by SEM using a Supra 40 with Gemini column operated at $3.00 \mathrm{kV}$. The oxide powders were spread on adhesive conducting carbon tapes and coated with a platinum (thickness layer: 7nm) by using a Quorum (Q150 T).

Nitrogen sorption analysis was performed with a Micromeritics ASAP 2020. Samples were preliminary degassed during $120 \mathrm{~min}$ to $10 \mu \mathrm{mHg}$ at $100{ }^{\circ} \mathrm{C}$. Brunauer-EmmettTaller (BET) model was applied to determine the specific surface area. The pore size distributions were calculated applying the Barret-Joyner-Halenda (BJH) method to the desorption branch of the isotherms. The assessments of microporosity were made from $\mathrm{t}$ plot construction $(0.2<\mathrm{t}<0.8 \mathrm{~nm})$ using the Harkins-Jura correlation.

Concerning the pore size distribution determination using this technique, we assumed that the samples are mechanically strong enough after calcination to withstand the pressure applied during the experiment.

The electronic conductivity was investigated with a homemade cell. This cell is made up of two copper electrodes inserted in a Teflon ring. Samples were pressed between these two electrodes. A potentiostat was used to impose a current of $105 \mathrm{~mA},-105 \mathrm{~mA}$ and $400 \mathrm{~mA}$ and the voltage was measured for each current. The homemade conductivity cell was placed under a press and measurements were performed without and with pressure at $0.5 \mathrm{~T}$ and $1 \mathrm{~T}$ at room temperature. The conductivity $(\sigma)$ was calculated with the formula $\sigma=\left(\mathrm{e} / \mathrm{R} * \mathrm{~S}_{\text {electrode }}\right)$, where $\mathrm{e}$ is the thickness of the sample, $\mathrm{R}$ the measured resistance and $S_{\text {electrode }}$ the surface of the electrode $\left(0.785 \mathrm{~cm}^{2}\right)$.

Samples were observed in HRTEM (High Resolution Transmission Electronic Microscopy) or HAADF/STEM (High-angular dark field scanning TEM) mode using a FEI-Tecnai Osiris microscope operating at $200 \mathrm{kV}$ and equipped with a Super-X system (4 Silicon Drift Detectors) optimized for high speed X-EDS measurement. The powder was dispersed in isopropanol and a drop was deposited on lacey film TEM grid.

Bulk chemical compositions was analysed by Energy dispersive X-ray spectroscopy (EDX).

In order to get the real platinum loading in our electrocatalysts atomic absorption spectrometry (AAS) measurements were performed. Electrocatalysts were treated with 
aqua regia during 20 hours to dissolve platinum. After centrifugation to separate the support powder, the Pt solution was collected. This solution was injected in the AAS (Perkin Elmer devise) in a mixture of air and acetylene. The Pt loading was calculated based on a calibration curve previously obtained.

Electrochemical measurements were carried out by the mean of a rotating disk electrode (RDE) with a potentiostat autolab-PGSTAT20. The working electrode (WE), with a geometric area of $0.196 \mathrm{~cm}^{2}$, was prepared as follow. The catalyst and Nafion ${ }^{\circledR}$ were dispersed in ultrapure water and sonicated until uniform catalytic ink was obtained. Catalytic inks were formulated to get a constant Pt loading of $60 \mu \mathrm{gPt} / \mathrm{cm}_{\text {geom }}{ }^{2}$. Nafion ${ }^{\circledR}$ quantities were adjusted in order to obtain the same film thickness $\left(2 \mathrm{mg}_{\text {nafion }} / \mathrm{m}_{\text {support }}{ }^{2}\right)$ whatever the developed area of the support. $80 \mu \mathrm{L}$ of this ink were deposited on the WE and dried at $110{ }^{\circ} \mathrm{C}$ in two successive steps ( $40 \mu \mathrm{L}$ each). Counter electrode is a Pt coil and the reference electrode was a MSE (mercury sulfate electrode). Electrolyte was a solution of $\mathrm{H}_{2} \mathrm{SO}_{4}$ at $0.1 \mathrm{M}$.

Cyclic voltammograms (CV) were recorded in Ar-saturated electrolyte solution. CV scan rate was $100 \mathrm{mV} / \mathrm{s}$ between 0.05 and $1.23 \mathrm{~V}$ vs RHE. Resulting curves were used to obtained the electrochemical surface areas (ECSA) of the catalyst. In order to measure the catalytic activity for the ORR, oxygen bubbling in the electrolyte solution was performed during $15 \mathrm{~min}$. Scan rate was $5 \mathrm{mV} / \mathrm{s}$ from $0,4 \mathrm{~V}$ to $1,05 \mathrm{~V}$ vs RHE. Measurements were carried out for electrode rotating speed of 400, 900, 1600 and 2500 rpm.

\section{Results and Discussion}

\section{Catalyst Support}

The catalyst support was selected based on the results of a previous study under review in the journal Chemistry of Materials. On top of chemical stability, the selection criteria were a high electronic conductivity, a large specific surface area and a multimodal pore size distribution. This led us to select a $10 \mathrm{wt} \% \mathrm{Sb}$ doped $\mathrm{SnO}_{2}$ aerogel.

Stable in the severe cathode side PEMFC operating conditions, it shows, after calcination in air at $600{ }^{\circ} \mathrm{C}$ for $5 \mathrm{~h}$, an electronic conductivity of $0.13 \mathrm{~S} / \mathrm{cm}$, a specific surface area of $85 \mathrm{~m}^{2} / \mathrm{g}$ and a bimodal pore size distribution centered on 25 and $45 \mathrm{~nm}$, with a negligible $\mu$ porous volume $\left(8.10^{-3} \mathrm{~cm}^{3} / \mathrm{g}\right)$. The introduction of antimony in the $\mathrm{SnO}_{2}$ aerogel matrix is impressively increasing the electronic conductivity. Indeed, without any antimony, the $\mathrm{SnO}_{2}$ aerogel showed an electronic conductivity of $2.10^{-5} \mathrm{~S} / \mathrm{cm}$ only.

The morphology based on a tridimensional network of interconnected nanoparticles (Cf figure 1) is particularly well adapted to the foreseen application. 


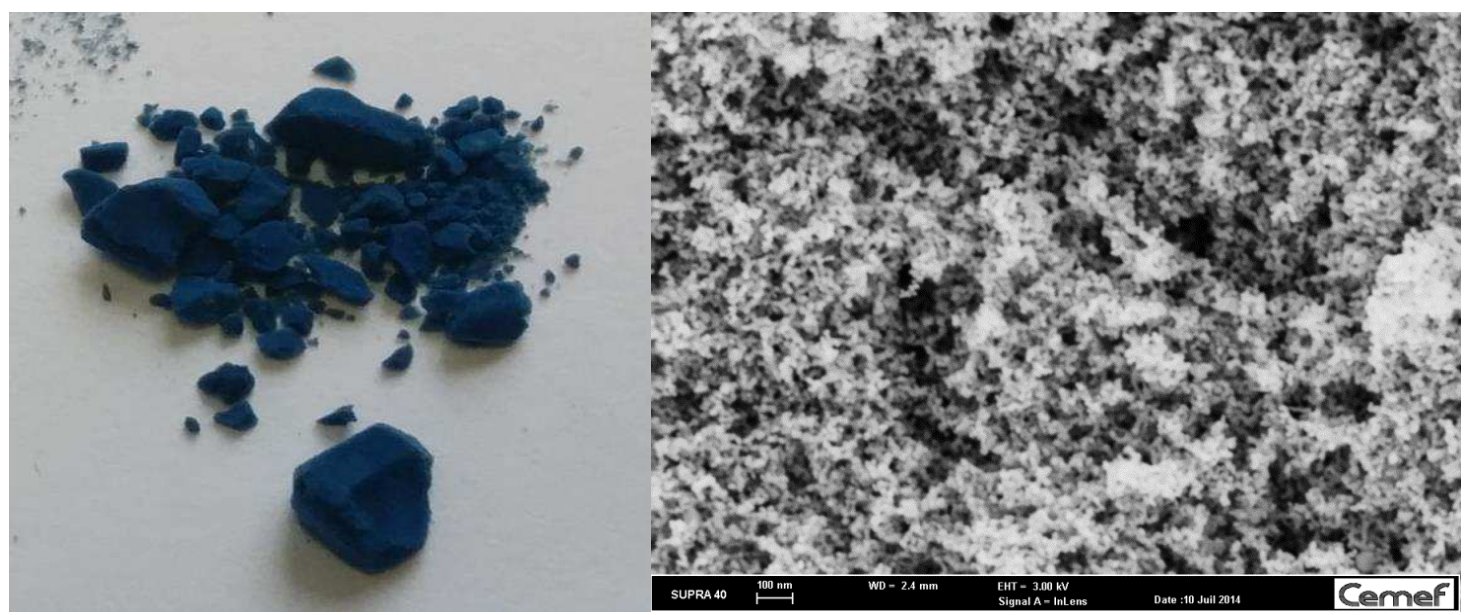

Figure 1. Photo (left) and SEM picture (right) of the selected catalyst support after calcination at $600{ }^{\circ} \mathrm{C}$ in air for $5 \mathrm{~h}: 10 \mathrm{wt} \% \mathrm{Sb}$ doped $\mathrm{SnO}_{2}$ aerogel.

After calcination at $600{ }^{\circ} \mathrm{C} \mathrm{SnO} 2$ : Sb crystallizes in the rutile form (Figure 2). No new peak was observed compared to undoped $\mathrm{SnO}_{2}$, but only a slight shift of peaks' position.

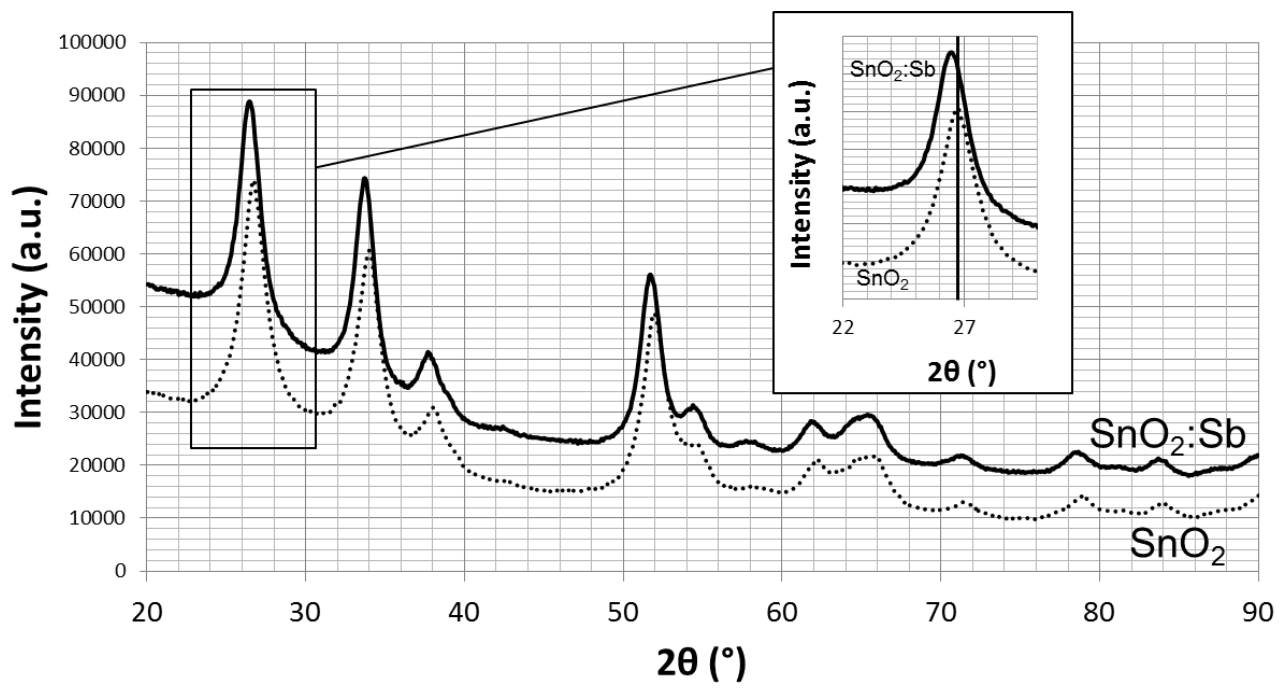

Figure 2. X-rays diffractogram of the selected catalyst support, $10 \mathrm{wt} \% \mathrm{Sb}$ doped $\mathrm{SnO}_{2}$ aerogel, compared to that of $\mathrm{SnO}_{2}$ (after calcination at $600{ }^{\circ} \mathrm{C}$ in air for $5 \mathrm{~h}$ ).

\section{$\underline{\text { Platinum Deposition }}$}

The three deposition protocols used in this study labelled A, B and C, are detailed in the experimental section.

TEM observations were realized to get information on both the Pt particles size and their distribution on the surface of the support. EDX was used to get a first rough 
estimation of the Pt amount deposited. In order to accurately analyze RDE results, a more precise quantification was realized by atomic absorption on selected samples. XRD was used to detect Pt and assess Pt crystallites' size.

Method A. Whatever the type of reduction $\left(\mathrm{H}_{2}\right.$ or UV), the platinum loading was estimated to $25 \mathrm{wt} \%$ by EDX. Very small nanoparticles were observed with TEM (HRTEM and HAADF/STEM). The Pt nanoparticles may be slightly larger after $\mathrm{H}_{2}$ reduction ( 3 to $4 \mathrm{~nm}$ ) compared to UV reduction ( 2 to $3 \mathrm{~nm}$ ). Their distribution on the surface of $\mathrm{SnO}_{2}$ : $\mathrm{Sb}$ seems be more even after UV reduction.
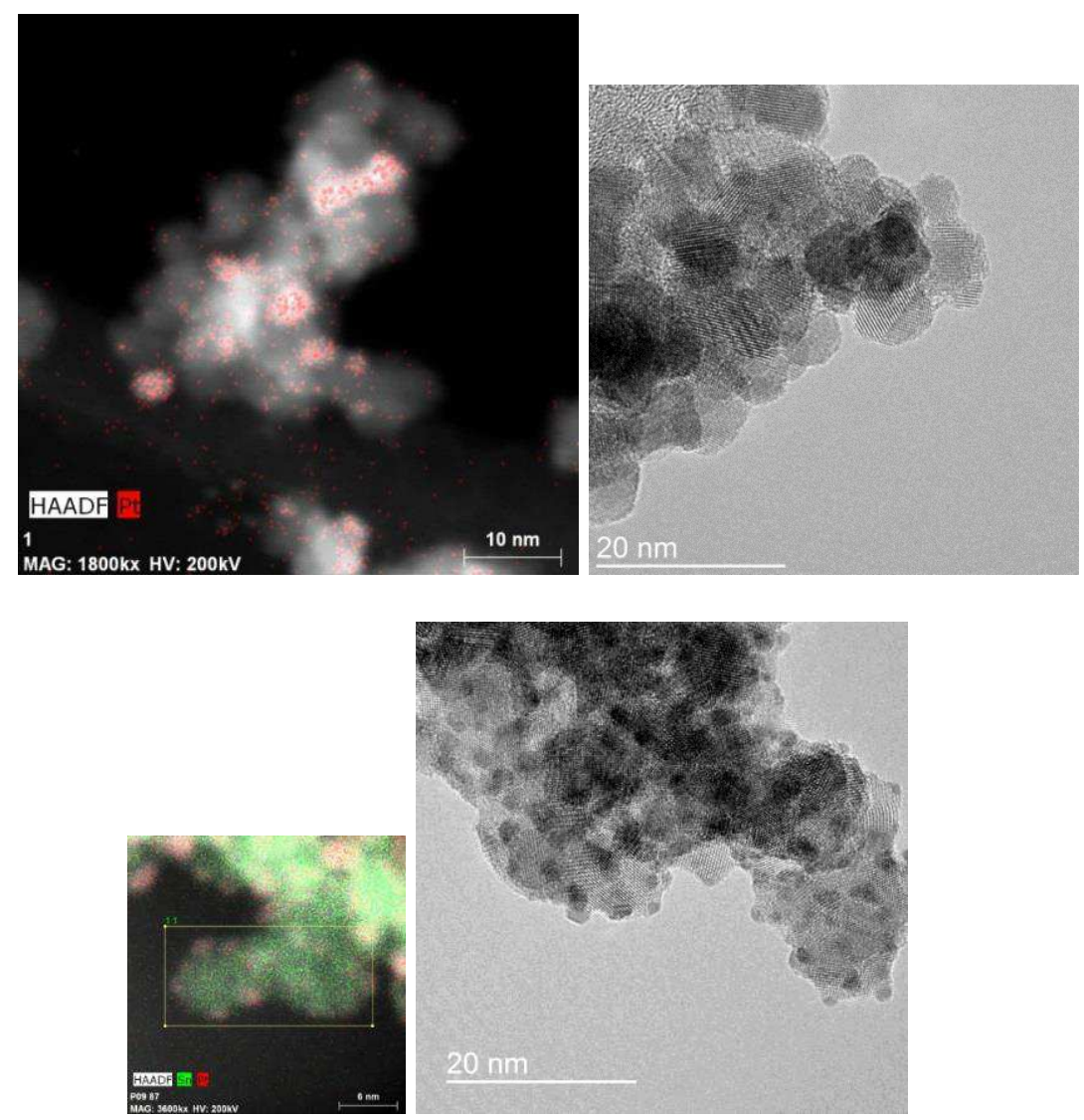

Figure 3. TEM pictures of of $\mathrm{Pt}-\mathrm{SnO}_{2}: \mathrm{Sb}$ after $\mathrm{H}_{2}$ reduction (top) and $3 \mathrm{~h} \mathrm{UV}$ reduction (bottom).

The UV irradiation time has quite no influence on their size. No difference could clearly be evidenced after 1, 3 or 5 hours of UV irradiation (Figure 4 ). $3 \mathrm{~h}$ was finally selected as a mean value. 

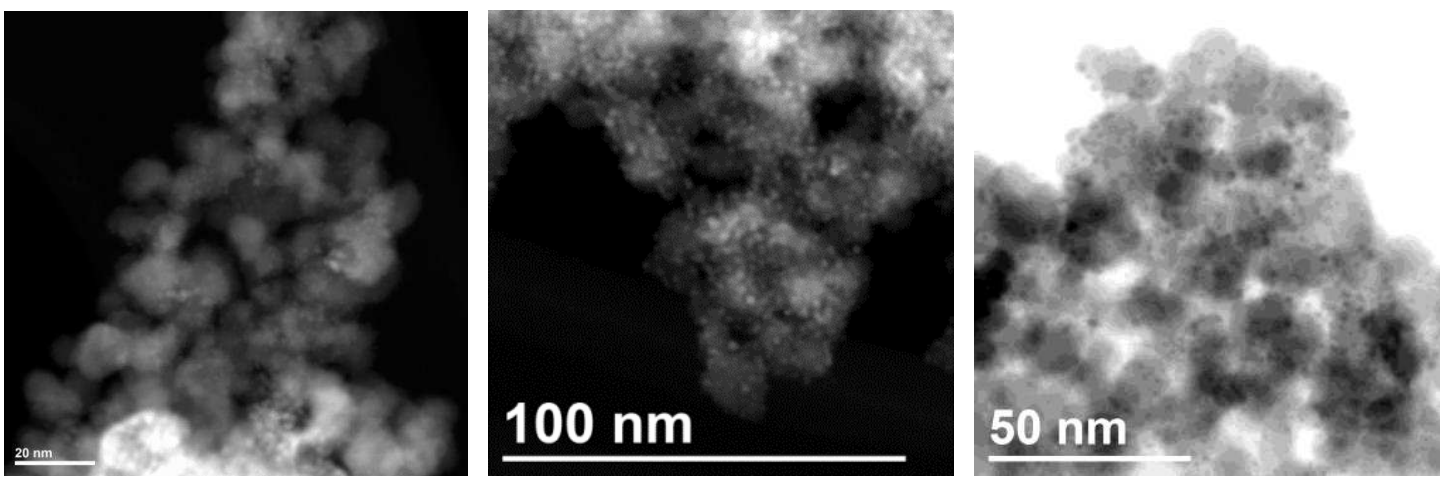

Figure 4. TEM pictures of of $\mathrm{Pt}-\mathrm{SnO}_{2}$ : $\mathrm{Sb}$ after different $\mathrm{UV}$ reduction time (left $=1 \mathrm{~h}$, center $=3 \mathrm{~h}$, right $=5 \mathrm{~h}$ ).

Pt could be detected with XRD on samples reduced with $\mathrm{H}_{2}$ (Figure 5). However, the diffraction peaks are so small that it was not possible to estimate the crystallites size.

Whatever the UV irradiation time (between 1 and 5h), Pt nanoparticles are so tiny that they could not be evidenced with XRD (Figure 6). The detection of Pt on samples reduced with $\mathrm{H}_{2}$ confirms that $\mathrm{Pt}$ nanoparticles are slightly larger than after $\mathrm{UV}$ irradiation. In both cases, it was impossible to calculate any crystallite sizes.
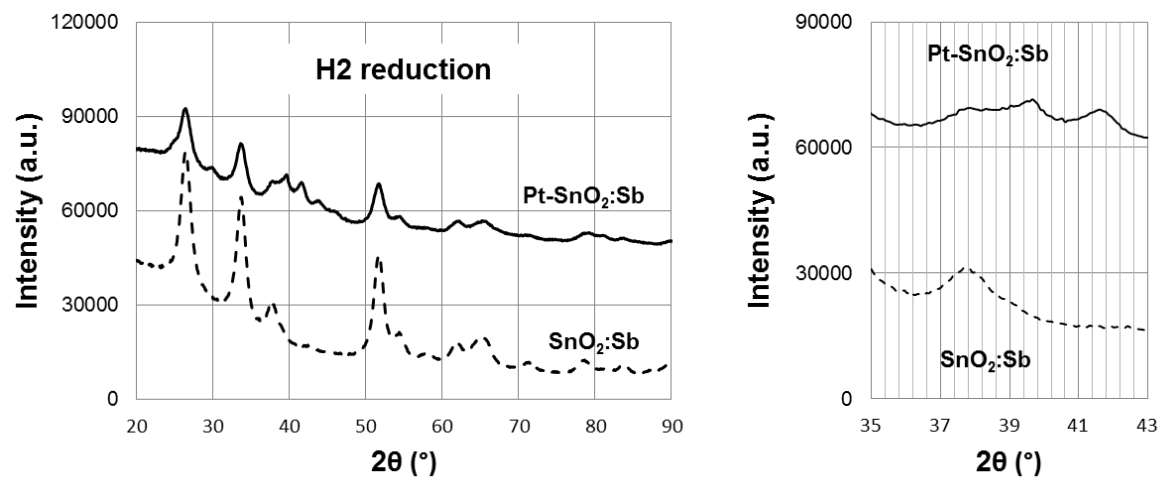

Figure 5. X-ray diffractograms of $\mathrm{Pt}-\mathrm{SnO}_{2}$ : $\mathrm{Sb}$ after $\mathrm{H}_{2}$ reduction, compared to that of $\mathrm{SnO}_{2}: \mathrm{Sb}$. 


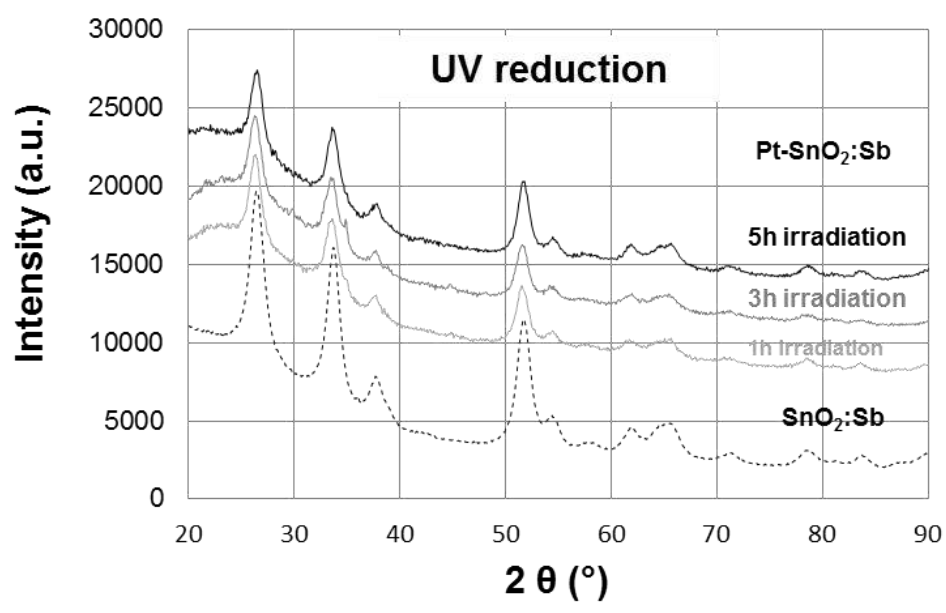

Figure 6. X-ray diffractograms of $\mathrm{Pt}-\mathrm{SnO}_{2}: \mathrm{Sb}$ after UV reduction, compared to that of $\mathrm{SnO}_{2}: \mathrm{Sb}$.

Method B. Whatever the type of reduction $\left(\mathrm{H}_{2}\right.$ or UV) and the $\mathrm{pH}$ of impregnation (2.8 or 3.8), the platinum loading was estimated to $30 \mathrm{wt} \%$ by EDX. The Pt nanoparticles are either much bigger than with method A or much more agglomerated.

After $\mathrm{H}_{2}$ reduction, particles or agglomerates are roughly 10 to $20 \mathrm{~nm}$ in diameter (Figure 7). If at $\mathrm{pH}=3.8$ very large nanoparticles seem to have been obtained $(10 \mathrm{~nm})$, at $\mathrm{pH}=2.8$, large agglomerates seem to be made up of nanoparticles of 2 to $3 \mathrm{~nm}$ in diameter.
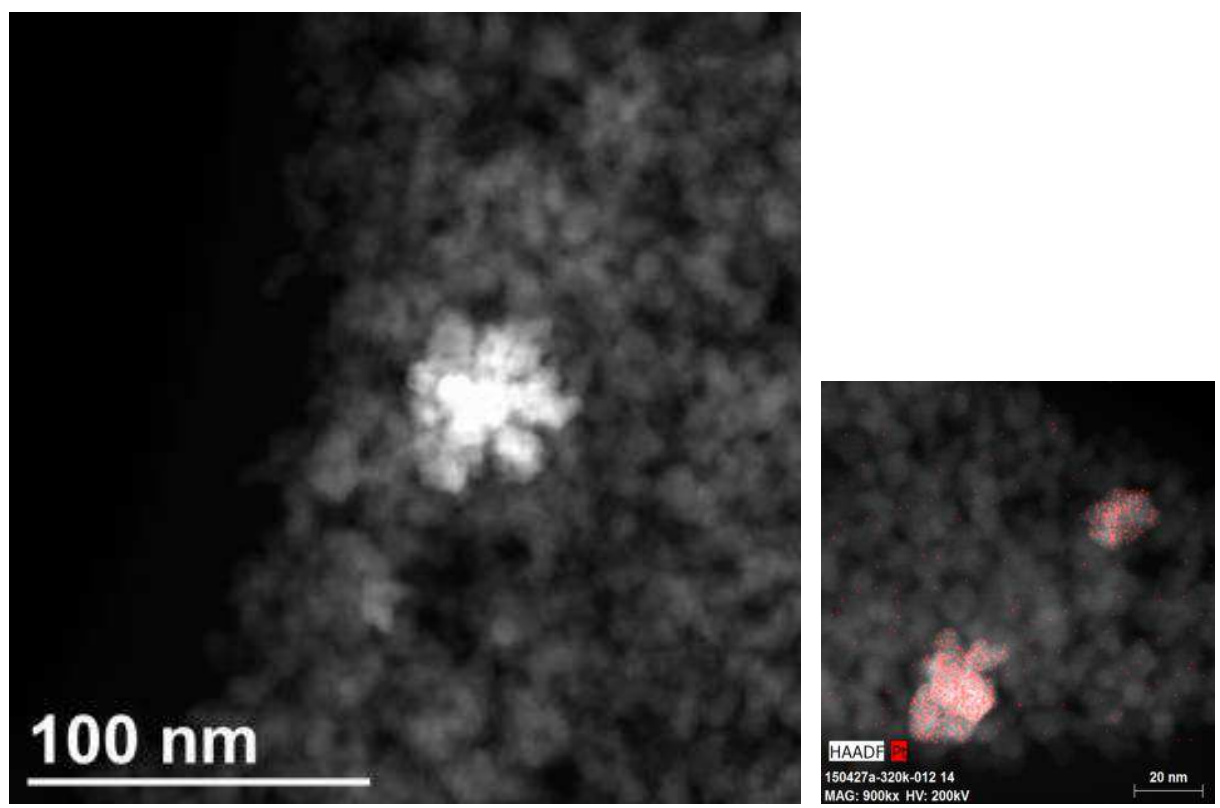

Figure 7. TEM pictures of $\mathrm{Pt}-\mathrm{SnO}_{2}: \mathrm{Sb}$, after $\mathrm{H}_{2}$ reduction, for 2 different $\mathrm{pH}$ of impregnation, 2.8 (left) and 3.8 (right). 
Even larger agglomerates (>50 nm) were observed after $3 \mathrm{~h} \mathrm{UV} \mathrm{reduction} \mathrm{(Figure} \mathrm{8).}$
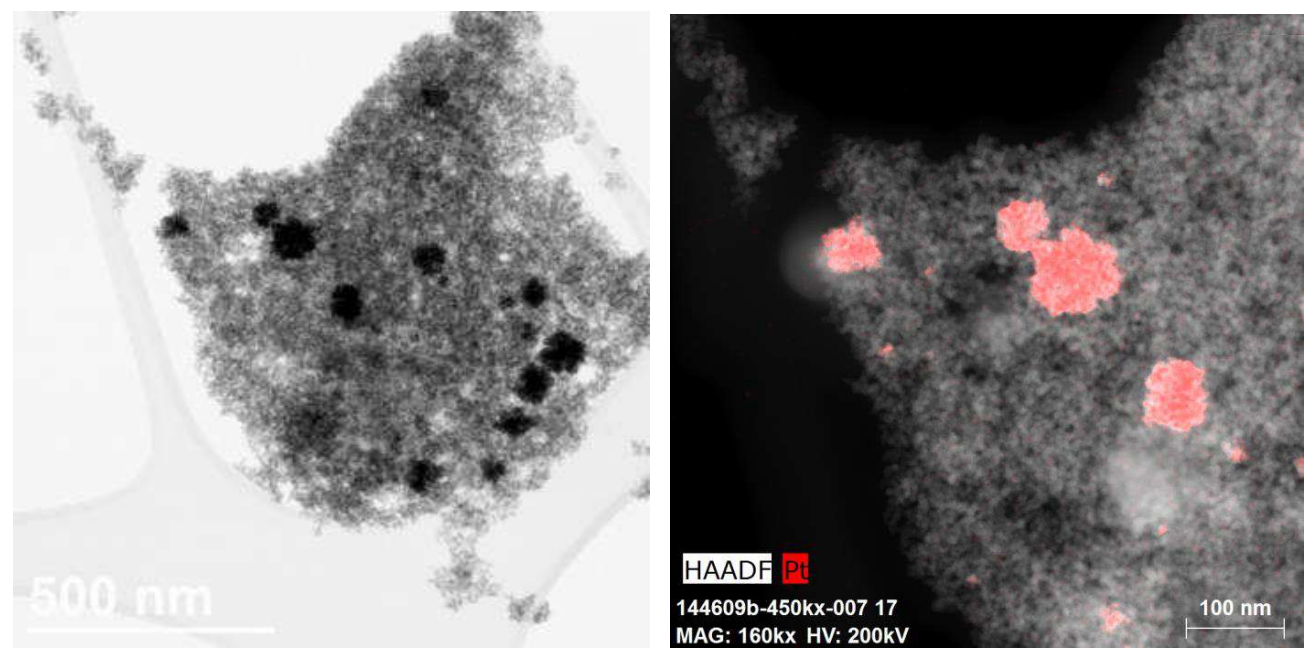

Figure 8. TEM pictures of $\mathrm{Pt}_{-} \mathrm{SnO}_{2}$ : $\mathrm{Sb}$, after UV reduction $(\mathrm{pH}$ of impregnation $=2.8$ ).

XRD (Figure 9) gave a clear evidence of the presence of platinum with characteristic peaks of Pt (111), (200), (220) and (311).
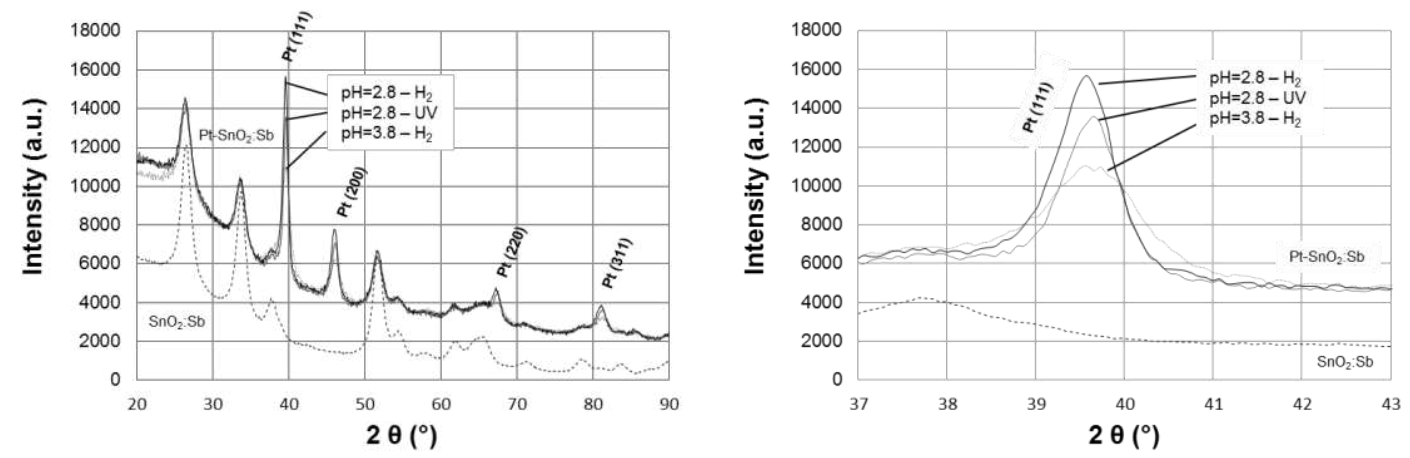

Figure 9. X-ray diffractograms of $\mathrm{Pt}-\mathrm{SnO}_{2}$ : $\mathrm{Sb}$ for different $\mathrm{pH}$ of impregnation (2.8 and $3.8)$ and different reduction routes $\left(\mathrm{H}_{2}\right.$ and $\left.\mathrm{UV}\right)$.

The Debye-Scherrer analysis of the diffraction peaks at $2 \theta=39.6^{\circ}$ allowed to estimate the Pt crystallites size for the different conditions of reduction. It came out that the crystallites size after UV reduction $(6.4 \mathrm{~nm})$ is smaller than after $\mathrm{H}_{2}$ reduction (7.7 and $9.8 \mathrm{~nm}$ respectively at $\mathrm{pH}=2.8$ and 3.8) as already observed with method $\mathrm{A}$ for $\mathrm{Pt}$ particles size. 
After $\mathrm{H}_{2}$ reduction, the higher the $\mathrm{pH}$ of impregnation, the larger the Pt crystallites. The value calculated at $\mathrm{pH}=3.8(9.8 \mathrm{~nm})$ is consistent with TEM observations (Figure 7) if the nanoparticles observed were single crystals. At $\mathrm{pH}=2.8$, the crystallites size was slightly smaller than at $\mathrm{pH}=3.8(7.7 \mathrm{~nm}$ vs $9.8 \mathrm{~nm})$ but larger than that of the individual particles observed by TEM.

Method C. Whatever the type of reduction $\left(\mathrm{H}_{2}\right.$ or $\left.\mathrm{UV}\right)$, the platinum loading was estimated to $25 \mathrm{wt} \%$ by EDX. Very large agglomerates were also observed with this method (Figure 10).

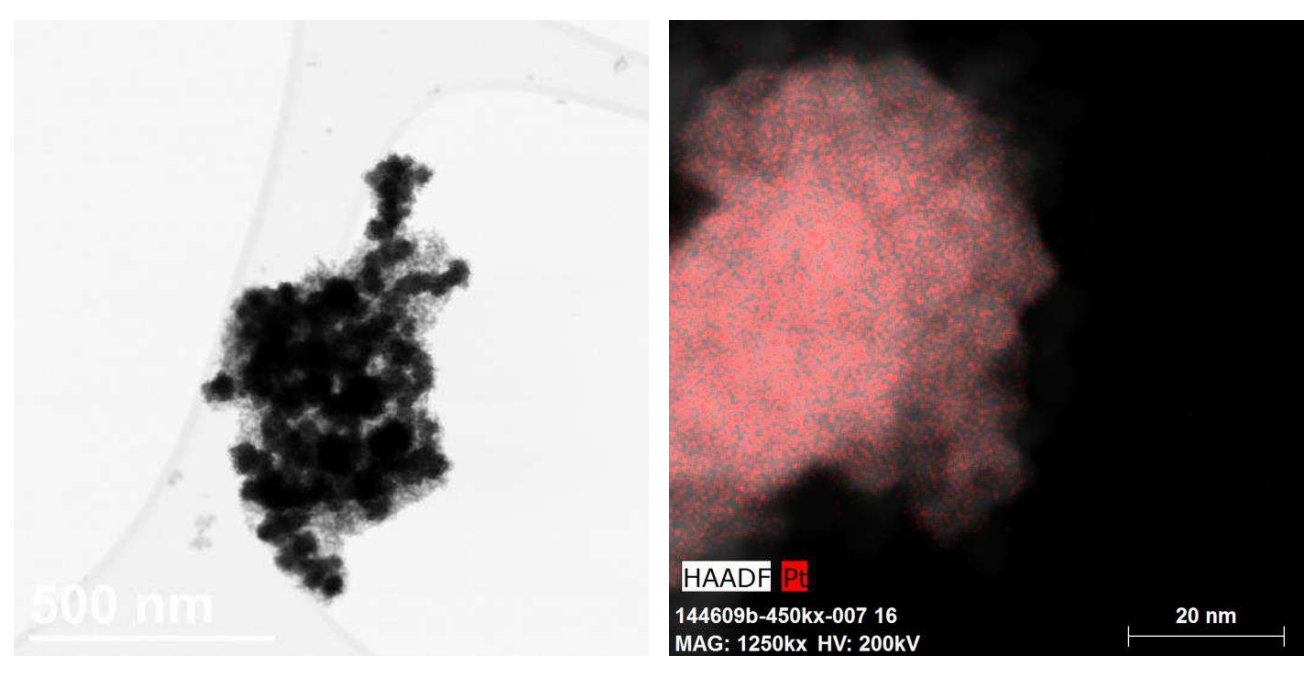

Figure 10. TEM pictures of $\mathrm{Pt}-\mathrm{SnO}_{2}$ : Sb obtained with method $\mathrm{C}$.

However no Pt could be detected with XRD (Figure 11). Individual Pt nanoparticles may thus be actually very small.

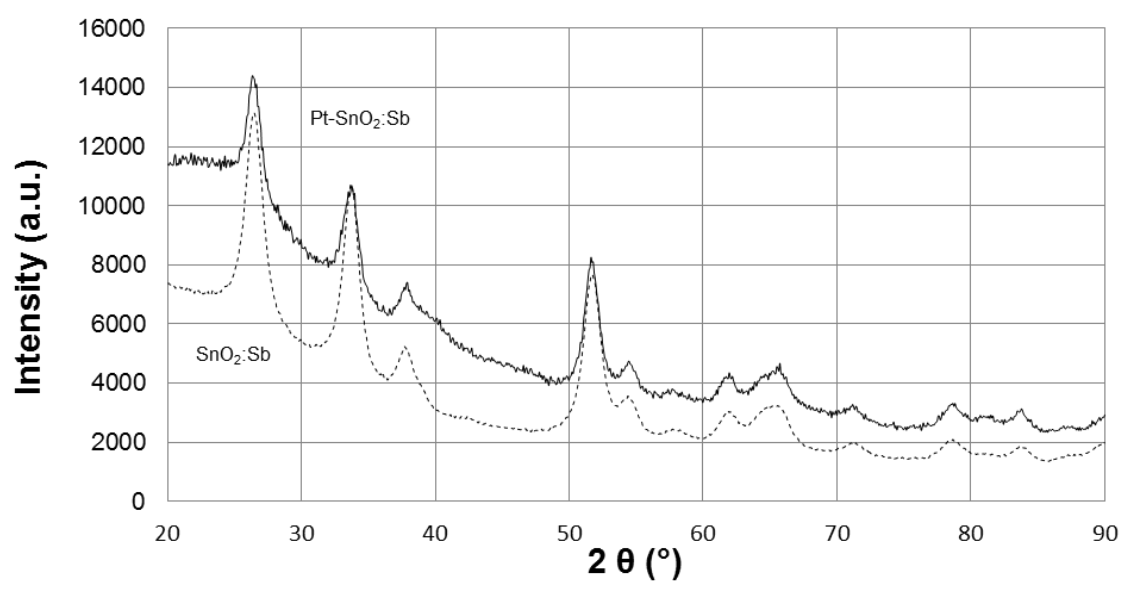

Figure 11. X-ray diffractogram of $\mathrm{Pt}-\mathrm{SnO}_{2}$ : Sb obtained with method $\mathrm{C}$ compared to that of $\mathrm{SnO}_{2}$ : Sb. 


\section{Electrochemical Activity}

Samples prepared with method $\mathrm{A}$ and $\mathrm{C}$ have been electrochemically characterized. Both their electrochemical surface area and oxygen reduction activity were compared to those of reference catalysts from Tanaka (TEC10E40EA, $40 \mathrm{wt} \% \mathrm{Pt}$ on graphitized carbon and TEC10V50E, $50 \mathrm{wt} \% \mathrm{Pt}$ on Vulcan CX-72) characterized in the same conditions.

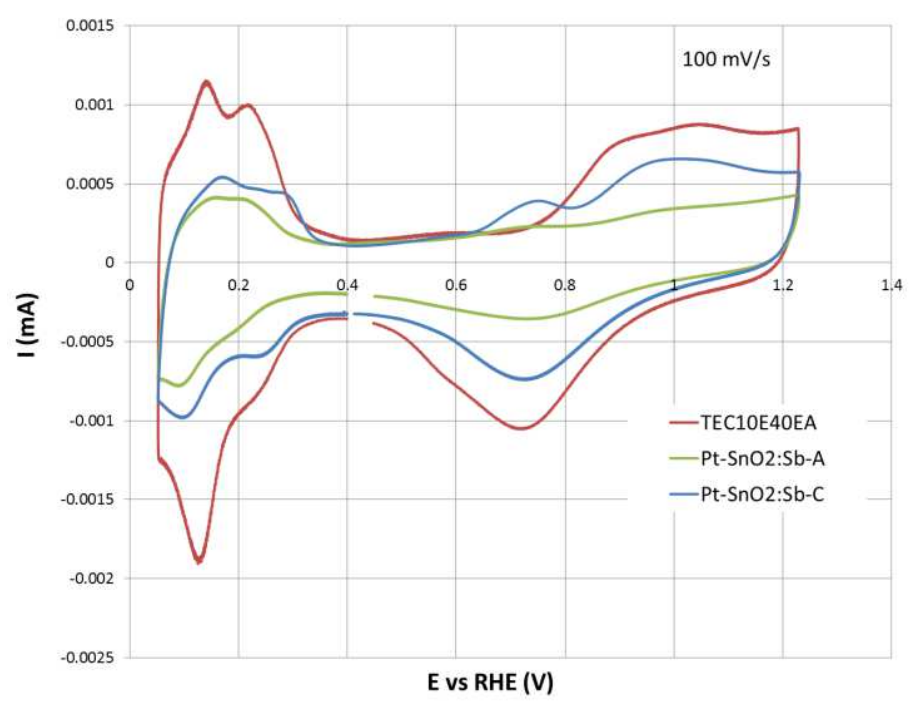

Figure 12. Cyclic voltammograms of $\mathrm{Pt}-\mathrm{SnO}_{2}: \mathrm{Sb}$ obtained with method $\mathrm{A}$ and $\mathrm{C}$ compared to that of TEC10E40EA in Ar-purged $0.1 \mathrm{M} \mathrm{H}_{2} \mathrm{SO}_{4}$.
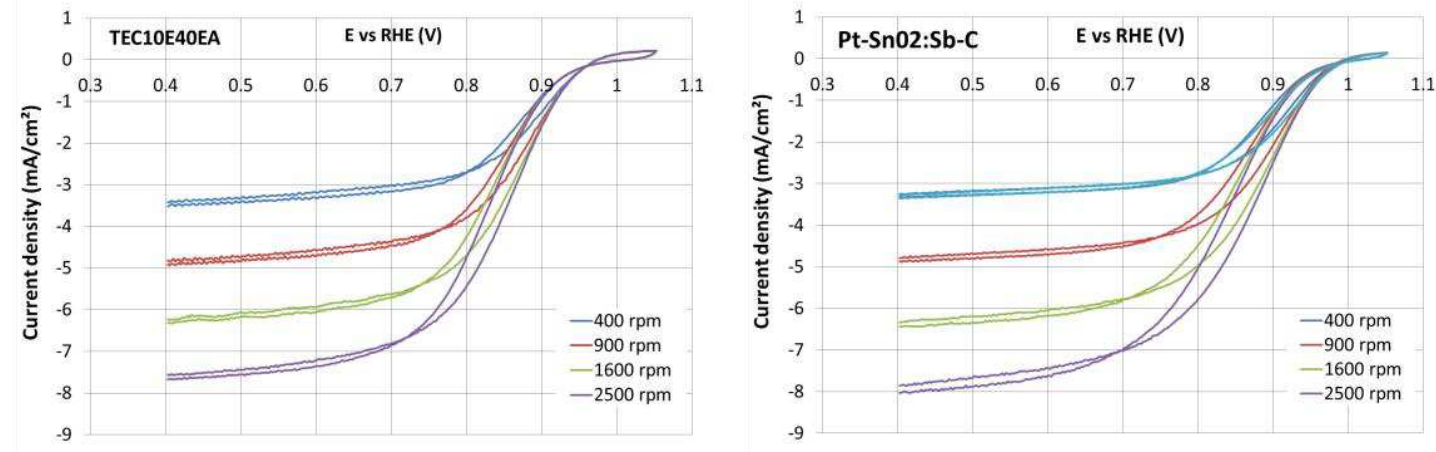

Figure 13. ORR activity of Pt-SnO 2 : $\mathrm{Sb}$ obtained with method $\mathrm{C}$ compared to that of TEC10E40EA in $\mathrm{O}_{2}$-saturated $0.1 \mathrm{M} \mathrm{H}_{2} \mathrm{SO}_{4}$.

TABLE I. Electrochemical characterization results

\begin{tabular}{ccc}
\hline Samples & $\begin{array}{c}\text { ECSA } \\
\left(\mathbf{m}^{2} / \mathbf{g}_{\mathbf{P t}}\right)\end{array}$ & $\begin{array}{c}\text { Is (ORR) } \\
\left(\mathbf{m A} / \mathbf{m g}_{\mathbf{P t}}\right)\end{array}$ \\
\hline TEC10V50E & $64^{1}$ & - \\
TEC10E40EA & $71^{2}$ & $11^{2}$ \\
$\mathrm{Pt}^{2} \mathrm{SnO}_{2}:$ Sb-A & $24^{1}$ & - \\
& $20^{2}$ & - \\
$\mathrm{Pt}^{2} \mathrm{SnO}_{2}: \mathrm{Sb}-\mathrm{C}$ & $37^{1}$ & - \\
& $32^{2}$ & $28^{1}$ \\
\hline
\end{tabular}

${ }^{1}$ Experimental setup 1

${ }^{2}$ Experimental setup 2 
Based on hydrogen adsorption region, shown in Figure 12 the calculated ECSA of $\mathrm{SnO}_{2}$ based electrocatalyst is significantly lower than that of the reference electrocatalyst. As shown in Figure 13, polarization curves for ORR of $\mathrm{Pt}-\mathrm{SnO}_{2}$ : Sb obtained with method C and TEC10E40EA show similar diffusion limited region between 0.4 and 0.75 V vs RHE.

The mass activity, calculated from Koutecky-Levich method, of $\mathrm{Pt}-\mathrm{SnO}_{2}: \mathrm{Sb}$ prepared with the method $\mathrm{C}$ is surprisingly higher than that of the reference electrocatalyst (see Table I) what will have to be confirmed.

\section{Conclusion}

$\mathrm{SnO}_{2}: \mathrm{Sb}$ at 10 at. \% aerogels synthetized show remarkable properties for the foreseen application. In addition to a high electronic conductivity of $0.13 \mathrm{~S} / \mathrm{cm}$, this material has a relatively high specific surface area of $85 \mathrm{~m}^{2} / \mathrm{g}$ with a bimodal pore size distribution centered at 25 and $45 \mathrm{~nm}$.

In terms of dispersion, platinum nanoparticles have been successfully deposited on the $\mathrm{SnO}_{2}$ : $\mathrm{Sb}$ aerogels surface. The electrocatalyst where Pt has been deposited with a $\mathrm{C}$ method shows the best ECSA, with a value of $37 \mathrm{~m}^{2} / \mathrm{g}_{\mathrm{Pt}}$, and has a mass catalytic activity even higher than a commercial carbon based electrocatalyst (TEC10E40EA), respectively 28 and $11 \mathrm{~mA} / \mathrm{mgPt}$ what will have to be confirmed.

\section{Acknowledgments}

The authors wish to thank Pierre Ilbizian for supercritical drying and the European FP7 program NANOCAT (SP1-JTI-FCH.2012.1.5) for funding

\section{References}

1. S. Mukerjee, J. Appl. Electrochem., 20, 537-548 (1990).

2. E. Antolini, Appl. Catal. B-Environ., 88, 1-24 (2009).

3. S. Maass, F. Finsterwalder, G. Frank, R. Hartmann, and C. Merten, J. Power Sources, 176, 444-451 (2008).

4. K. Yasuda, A. Taniguchi, T. Akita, T. Ioroi, and Z. Siroma, Phys. Chem. Chem. Phys., 8, 746-752 (2006).

5. S. H. K. Sasaki, K. Kanda, Y. Takabatake, T. Tsukatsune, T. Higashi, F. Takasaki, Z. Noda, and A. Hayashi, The Electrochem. Soc. Meeting Abstracts, 1684 (2012).

6. A. Masao, S. Noda, F. Takasaki, K. Ito, and K. Sasaki, Electrochem. Solid State Lett., 12, B119-B122 (2009).

7. P. Zhang, S.-Y. Huang, and B. N. Popov, J. Electrochem. Soc.,157, B1163-B1172 (2010).

8. F. Takasaki, S. Matsuie, Y. Takabatake, Z. Noda, A. Hayashi, Y. Shiratori, K. Ito, and K. Sasaki, J. Electrochem. Soc., 158, B1270-B1275 (2011).

9. M. P. Gurrola, M. Guerra-Balcazar,; L. Alvarez-Contreras, R. Nava, J. LedesmaGarcia, and L. G. Arriaga,, J. Power Sources, 243, 826-830 (2013). 
10. M. Yin, J. Y. Xu, Q. F. Li, J. O. Jensen, Y. J. Huang, L. N. Cleemann, N. J. Bjerrum, and W. Xing., Appl. Catal. B-Environ., 144, 112-120 (2014).

11. K. Kakinuma, Y. Chino, Y. Senoo, M. Uchida, T. Kamino, H. Uchida, S. Deki, and M. Watanabe., Electrochim. Acta, 110, 316-324 (2013).

12. K. Kakinuma, M. Uchida, T. Kamino, H. Uchida, and M. Watanabe, Electrochim. Acta, 56, 2881-2887 (2011).

13. Y. Senoo, K. Taniguchi, K. Kakinuma, M. Uchida, H. Uchida, S. Deki, and M. Watanabe., Electrochem. Commun., 51, 37-40 (2015).

14. S. J. Tauster and S. C. Fung, J. Catal., 55, 29-35 (1978).

15. M. S. Spencer, J. Catal., 93, 216-223 (1985).

16. N. Kamiuchi, T. Matsui, R. Kikuchi, and K. Eguchi, J. Phys. Chem. C, 111, 16470-16476 (2007).

17. T. Matsui, K. Fujiwara, T. Okanishi, R. Kikuchi, T. Takeguchi, and K. Eguchi,, J. Power Sources, 155, 152-156 (2006).

18. T. Matsui, T. Kanishi, K. Fujiwara, K. Tsutsui, R. Kikuchi, T. Takeguchi, and K. Eguchi , Sci. Technol. Adv. Mater., 7, 524-530 (2006).

19. T. Okanishi, T. Matsui, T. Takeguchi, R. Kikuchi, and K. Eguchi, Appl. Catal. AGeneral, 298, 181-187 (2006).

20. M. Arenz, V. Stamenkovic, B. B. Blizanac, K. J. J. Mayrhofer, N. M. Markovic, and P. N. Ross,, J. Catal., 232, 402-410 (2005).

21. S. M. Andersen, C. F. Norgaard, M. J. Larsen, and E. Skou, J. Power Sources, 273, 158-161 (2015).

22. J.C. Yang, Y.C. Kim, Y.G. Shul, C.H. Shin, and T.K. Lee, Appl. Surface Sci. 121/122, 525-529 (1997). 